\title{
ROKOK, ALKOHOL DAN CINTA: TIGA PERBINCANGAN MENUJU "SURGA" (PEMAKNAAN AUDIENS FILM CONSTANTINE DALAM RANAH FIKSI PENGGEMAR)
}

\author{
Yongky Gigih Prasisko \\ Kajian Budaya dan Media Universitas Gadjah Mada \\ Jln. Teknika Utara, Pogung, Yogyakarta \\ Email: yongky.g.prasisko@gmail.com
}

\begin{abstract}
Abstrak
Peralihan media tradisional menuju media baru memberikan perubahan sistem komunikasi media dengan audiens, yang semula bersifat transmitif, narrowcast dan terpusat menjadi dialektis, broadcast dan tersebar. Media baru menyediakan ruang bagi audiens untuk memaknai konten media, dengan sistem dialektisnya, makna menjadi plural dan heterogen. Audiens bukan lagi objek pasif melainkan subjek yang aktif berpartisipasi dalam media. Konsep audiens aktif mendapatkan bentuk materinya pada fiksi penggemar di situs fanfiction.net, dalam konteks ini audiens film Constantine, mereka membuat cerita fiksi dengan masih menggunakan tokoh dan seting film, sebagai bentuk interpretasi dan pemaknaan baru terhadap film. Dalam ranah fanfiction, telah tercipta ruang dialektis antara audiens dengan media, yang melaluinya, makna-makna baru akan terus muncul dari beragam interpretasi audiens.
\end{abstract}

Kata kunci : Audien, fanfiction, Constantine, ekstase, investasi

\begin{abstract}
The transition of traditional media toward new media provide the change of media communications system toward the audience; which is originally transmitive, narrowcast and centralized become dialectical, broadcast and scattered. New media provides a space for the audience to interpret media content, with its dialectic system, the meaning become plural and heterogeneous. Audiences are no longer a passive object but subjects who actively participated in the media. The concept of an active audience get the material in the form of fan fiction on fanfiction.net site, in this context Constantine movie audience, make a fictional story with characters and settings are still using film as a new form of interpretation and meaning of the film. In the realm of fanfiction, has created dialectic between the audiences with the media, through which new meanings will continue to emerge from the diverse audience interpretation.
\end{abstract}

Keywords: Audience, fanfiction, Constantine, ecstasy, investment

\section{Media Tradisional Menuju Media Baru}

Media memiliki dualitas bentuk yaitu sebagai institusi bisnis dan agen penyalur informasi. Sebagai institusi bisnis, media tidak bisa terlepas dari pihak-pihak pemberi dana serta mempunyai kecenderungan untuk meraup keuntungan. Media membutuhkan sumbersumber dana seperti investor maupun pengiklan untuk membiayai kegiatan operasionalnya. Hal tersebut turut mempengaruhi dalam kegiatan produksi konten, distribusi sampai pada konsumsi masyarakat. Pengaruhnya dapat berbentuk kecenderungan konten berita pada pihak-pihak tertentu atau penyaluran kepentingan tertentu seperti kampanye dan pencitraan, bahkan dalam media koran atau televisi, iklan banyak mengambil porsi tayangan. Dengan demikian konten dalam media dipandang tidak bersifat netral. Bentuk kedua, sebagai penyalur informasi kepada publik, media memberikan ruang bagi masyarakat untuk berinteraksi dengan negara ataupun antar individu dan kelompok sosial. Namun, interaksi ini masih bersifat kanonis, hanya individu dan kelompok tertentu saja yang memiliki akses pada media.

Muncul kemudian media baru, lebih demokratis karena akses lebih mudah serta menyebar di seluruh dunia, media ini bernama internet. Di satu sisi internet memberikan ruang 
bebas untuk publik dalam memproduksi berita dan informasi. Situs-situs banyak disediakan di dalam internet, yang dapat digunakan sebagai ruang audiens untuk secara aktif terlibat dan berpartisipasi mempublikasikan opini, kritik atau karya kreatif. Hal ini turut merubah sudut pandang bahwa audiens bukalah objek pasif namun agen yang aktif dalam memaknai konten media, memproduksi dan menggunakan media tersebut. Konsep audiens aktif dapat dijelaskan melalui konsep uses and gratification oleh Severin \&Tankard, 1997, yaitu bukan apa yang dilakukan media untuk publik tetapi apa yang publik lakukan dengan media. Audiens bukanlah massa yang homogen namun cenderung plural dengan berbagai macam interpretasi dan respon. Melalui internet, audiens mempunyai otoritas untuk menggunakan media website demi kepentingan-kepentingan mereka. Dalam hal ini, mereka mempunyai kesempatan untuk mengubah sistem hubungan media dan audiens yang narrowcast, trasmitif dan berjalan satu arah menjadi sistem broadcast, dialektis dan bersifat timbal balik. Sebagai contoh, dalam Hesmondhalgh (2010), fenomena user content generated di internet menjelaskan bagaimana khalayak memproduksi konten media dan sekaligus mendistribusikan serta menjadi konsumen dari konten tersebut. Kebutuhan audiens akan sebuah pemaknaan kembali terhadap konten media, telah terakomodasi dengan hadirnya internet, yang juga berarti bahwa makna tidak hanya terdapat pada proses produksi melainkan dapat muncul ketika dalam proses konsumsi. Hal ini dijelaskan dalam model komunikasi encoding-decoding Stuart Hall, yakni makna yang diproduksi media tidak selalu sama dengan resepsi makna oleh audiens, mereka secara aktif menerima, menegoisasikannya bahkan menegasikannya, sehingga maknamakna baru akan muncul.

\section{Fanfiction}

Fanfiction atau disebut juga fiksi penggemar merupakan suatu upaya audiens untuk memaknai atau menginterpretasi konten media, antara lain film, novel, komik, game maupun program televisi. Audiens atau fans diberi kebebasan dan otoritas untuk memaknai ulang karya kreatif yang telah dipublikasikan oleh si penulis cerita melalui produksi cerita baru mengenai tokoh dan seting dalam karya kreatif tersebut atau penggabungan elemen karya satu dengan yang lain. Karya fans tersebut tidak memiliki hak cipta, hanya mendapatkan kesempatan untuk mempublikasikan ceritanya di media online, melalui situs www.fanfiction. net. Dalam situs tersebut, karya mereka akan dibaca oleh fans-fans lain maupun publik yang kemudian dapat memungkinkan munculnya cerita-cerita baru. Di sini, pemaknaan ulang akan sebuah karya kreatif akan berlangsung terus menerus dan memunculkan kekayaan makna dengan berbagai macam interpretasi audiens.

Objek kajian dalam penelitian ini fokus kepada pemaknaan audiens pada film Hollywood berjudul Constantine (2005) dalam media online, www.fanfiction.net, di dalamnya, terdapat perbincangan mengenai religiusitas seseorang seperti doa, Tuhan, malaikat, setan, neraka dan surga. Elemen-elemen tersebut memungkinkan untuk memicu berbagai macam interpretasi dari penikmat film Constantine. Otoritas penafsiran ajaran religi masih kuat dipegang oleh para pemuka agama beserta dengan ahli tafsir kitab suci, yang mengakibatkan makna bersifat kanonis, ada legitimasi untuk para produser makna yang diberikan hak untuk memberikan sebuah kebenaran. Tokoh utama, John Constantine, memiliki pemaknaan tersendiri terhadap religiusitasnya. Berbeda dengan kebanyakan orang, yaitu mereka yang menapaki jalan menuju surga dengan menempuhnya melalui praktik-praktik ibadah sebagai investasi akses menuju surga, John Constantine menempuh surga bukan dengan jalan praktik ibadah, namun melalui tindakan pengusiran setan, pengorbanan dan cinta. Dia mengaku bukan orang yang religius, dia sangat dekat dengan rokok dan alkohol, produk konsumsinya sehari-hari. Pemaknaan akan religiusitas menjadi lebih kaya ketika audiens, atau fans film Constantine, diberi 
kesempatan untuk menginterpretasi elemenelemen dari sebuah keyakinan. Dengan masih menggunakan karakter dan seting film tersebut, audiens atau fans mengkonstruksi plot cerita baru yang merupakan refleksi dari pemaknaan dan interpretasi baru. Pemaknaan religiusitas menjadi penting ketika usaha-usaha untuk mendobrak makna dominan terakomodasi melalui media internet, sehingga makna kanonis menjadi lebih pural.

\section{Sinopsis Film Constantine}

Dipublikasikan pada tahun 2005, film Constantine bercerita tentang kehidupan sang tokoh utama, John Constantine, yang mempunyai kemampuan melihat hal-hal gaib, dalam menghadapi konflik dengan malaikat, setan dan aturan-aturan keseimbangan. Film bermula ketika John Constantine dipanggil oleh salah satu keluarga untuk melakukan pengusiran setan yang berdiam dalam diri seorang gadis. Dia berhasil mengeluarkan setan dari dalam tubuh gadis tersebut dan mengirim setan kembali ke tempat asalnya, neraka. Dari sini tokoh John Constantine, diperkenalkan sebagai, seorang perokok berat, penderita kanker dan seorang cenayang yang mampu melawan kekuatan setan. Pekerjaannya bertujuan untuk menjaga aturan keseimbangan antara makhluk gaib dan manusia. Aturan tersebut menjelaskan bahwa baik setan maupun malaikat tidak diperbolehkan melakukan kontak langsung dengan manusia, hubungan mereka dengan manusia hanyalah berbentuk pengaruh. Ketika ada salah satu pihak melanggar aturan keseimbangan, setan ataupun malaikat, maka dia berkewajiban untuk mengirim mereka kembali ke alamnya.

$$
\text { Plot berlanjut dengan misteri }
$$

terbunuhnya adik Angela Dodson, seorang detektif wanita. Dia meyakini bahwa kematian adiknya, Isabel Dodson, bukan disebabkan karena keinginannya untuk bunuh diri, karena adiknya adalah seorang religius yang taat. Angela meyakini ada pengaruh kekuatan diluar Isabel, ada makhluk gaib merasuki dirinya untuk kemudian mendorongnya melakukan tindakan bunuh diri. Ternyata, adiknya juga memiliki kemampuan melihat hal-hal gaib, dan hal itu menyebabkan dirinya menjadi stress dan dirawat di rumah sakit sebelum dia bunuh diri. Angela kemudian bertemu dengan Constantine, berharap dia bisa membantu mengungkap misteri kematian Isabel. John Constantine bersedia membantu Angela dan menjelaskan bahwa ada pertarungan antara malaikat dan setan dengan nyawa seluruh umat manusia sebagai taruhannya. Hal ini dibuktikan ketika Mammon, anak Lucifer, berusaha untuk mendirikan kerajaannya di dunia. Untuk itu, Mammon membutuhkan bantuan Tuhan, melalui seorang yang memiliki psikis kuat, juga memiliki kemampuan melihat hal-hal gaib serta religius. Orang tersebut tak lain adalah Angela.

Untuk memuluskan rencananya, iblis bernama Balthazar, membunuh temanteman Constantine yang berusaha untuk membantunya dalam mengungkapkan rencana lahirnya Mammon. Constantine kemudian membunuh Balthazar namun Angela berhasil diculik. Ternyata, rencana ini berasal dari malaikat, Gabriel, dia menginginkan Mammon untuk lahir ke dunia dengan alasan dia menyayangkan sikap pilih kasih Tuhan yang lebih memilih mengasihi manusia, Gabriel percaya bahwa dengan membawa alam neraka ke dunia akan menjadikan manusia sadar akan kecintaan Tuhan melalui pertobatan dan kepercayaan yang sebenar-benarnnya. Namun, akhirnya rencana tersebut gagal, Constantine memanggil Lucifer dengan mengorbankan dirinya demi Angela, dia mencoba bunuh diri, sehingga Lucifer datang akan mencabut nyawanya. Constantine menceritakan rencana Gabriel kepada Lucifer, Lucifer tidak ingin aturan keseimbangan.dilanggar, dan kemudian dia membawa anaknya, Mammon, kembali ke neraka. Karena pengorbanannya, Constantine dalam keadaan sekarat, jiwanya akan masuk ke surga, namun Lucifer menghidupkannya kembali dengan alasan, dia tidak ingin Constantine masuk surga, sudah merupakan keinginan Lucifer untuk membawa Constantine ke neraka dengan tangannya sendiri. 


\section{Rokok, Alkohol dan Cinta: Tiga Perbincangan Menuju Surga}

Memaknai pelarian, sama halnya ketika berbicara tentang kebebasan, perjuangan menuju sebuah dunia otonom ketika diri dimiliki secara penuh. Ketika orang mengalokasikan dirinya kepada tatanan simbolik untuk berproduksi, serta keberjarakan antara tubuh dan jiwa yang semakin senjang, maka akan muncul usaha-usaha untuk keluar menuju subjek otonom. Menjalani hidup sehari-hari secara statis, berulang-ulang dengan pola yang seragam adalah demi mencapai satu tujuan, melalui disiplin dengan tingkatan tahap kerja, yaitu kebahagiaan. Namun, melihat fenomena tersebut, kebahagiaan dimaknai sebagai nilai ideal yang dapat dicapai melalui instrument kapital materi.

Perihal sebuah pelarian, adalah merupakan usaha untuk mencapai kebahagiaan, entah sementara ataupun selamanya. Ruang-ruang itu tersedia bagi para pencari kebahagiaan duniawi, di sudut-sudut kota, ketika hari sudah beranjak petang maka kehidupan mereka telah dimulai. Mereka bahagia, barangkali hal itu yang mereka rasakan ataukah hanya kesenangan semata nan sementara, hal inilah yang mungkin mereka lupakan. Kesenangan malam ini hanya untuk sembuhkan diri, dan esoknya berlanjut kembali kepada tatanan hidup statis. Cerita mulai dirajut kembali, menjadi sebuah motif dan corak kehidupan, dan setelahnya diretas untuk diurai satu persatu kemudian dihamburkan ke udara setinggi-tingginya.

Perbincangan tentang rokok, bukan hanya persoalan tentang kesehatan namun juga dimensi lain seperti gaya hidup, dengan wacana nilai rokok yang telah melegalkan praktik merokok beserta produksi dan distribusinya. Gaya hidup yang dimaknai dalam mikro politik, adalah tindakan dan perilaku individu maupun kelompok yang merupakan refleksi dari cara mereka hidup dan berinteraksi antar sesama. Produk bisa jadi menjadi sebuah objek pelarian, dengan industri sebagai subjek, penyedia, untuk mengarahkan orang-orang kepada sebuah tujuan yaitu konsumsi.
Begitu juga dengan minuman beralkohol, ketika ruang-ruang transaksi memberikan akses mudah, serta tersedia banyaknya tempattempat hiburan seperti bar atau club malam, maka wacana akan bekerja melaluinya. Di bar, misalnya, minum minuman keras merupakan sesuatu yang lazim, malah jika tidak sampai mabuk dianggap sebagai hal yang tabu. Alkohol dan mabuk menjadi sebuah keharusan untuk dikonsumsi supaya dapat diterima oleh komunitas dalam ruang-ruang tersebut.

Keberlangsungan kehidupan malam, memberikan satu unsur yang barangkali jarang sekali hadir yaitu cinta. Interaksi antar individu di dalamnya hanya digerakkan oleh motif uang, hasrat dan nafsu. Laki-laki dan wanita saling bertemu, berkenalan dan berakhir di ranjang belakang. Namun, hal tersebut tidak menutup kemungkinan akan hadirnya penyelamat yang membimbing kepada sebuah kebebasan, kebermaknaan hidup dan menuntun ke arah kebahagiaan yang sesungguhnya bukan sekedar kesenangan belaka.

\section{Pemaknaan Film Constantine dalam Ranah Fiksi Penggemar (Fanfiction)}

Film Constantine turut memperbincangkan perihal rokok, alkohol dan cinta yang secara khusus ditampilkan melalui tokoh John Constantine. Dia adalah seorang perokok berat, yang karenanya mengalami gangguan, kanker, pada paru-parunya. Dia sekaligus juga peminum alkohol, di tempat tinggalnya tersimpan beberapa botol minuman keras. Perihal rokok diperbincangkan dalam adegan ketika Constantine memeriksakan kesehatannya pada dokter, dokter memperingatinya untuk berhenti merokok karena penyakit paru-parunya semakin parah. Dia menolak untuk berhenti merokok dan akan meneruskan kebiasaannya selagi dia masih hidup karena hidupnya telah dikutuk. Cerita kemudian dielaborasi oleh penulis Fanfiction bernama akun TravelingThroughTime, tulisan fiksinya berjudul Smoke, Drink. And Learn To Love. Dengan masih mempertahankan kebiasaan dan keras kepalanya, Constantine kemudian pergi ke bar, menikmati minuman keras dan bertemu 
dengan seorang wanita bernama Ellie. Cerita pertemuan ini kemudian dia lanjutkan dan maknai sendiri, seperti yang tertera pada kutipan di bawah ini.

"I'm Ellie.' she grins.

'Constantine." he replies with little expression.

I know', she states. 'I've heard a lot about you.'

'You want something?' there he goes being rude again.

Not me, but you look like someone who could use a drinking ner.'...............

She taps her fingers on the hood and turns to look at him. He merely lifts a brow and she already knows what he's wanting to ask.

Let's go for a ride,' she suggests" (TravelingThroughTime:2008).

Tulisan tersebut merupakan bukti bahwa melalui media website, khususnya www. fanfiction.net, audiens mampu memproduksi cerita sendiri yang tidak terlepas dari cerita film Constantine. Tidak hanya itu, audiens mempunyai otoritas untuk memaknai film tersebut dengan masih menggunakan tokohtokoh dalam film. Selain perubahan plot, perubahan perwatakan tokoh memungkinkan untuk terjadi yang kemudian dimaknai kembali dengan menambahkan karakteristik tokoh melalui produksi cerita fiksinya. Ketika John Constantine sedang menikmati rokok dan minuman beralkohol di Midnite bar, dia bertemu dengan Ellie, pembawa kebebasan bagi suntuknya kehidupan John. Ellie mengajak John keluar untuk mencari kebebasan, berkendara dengan mobil menikmati indahnya malam. Selama ini, pelarian kehidupan John adalah rokok dan alkohol, kemudian seorang fanfic, TravelingThroughTime, memberikan pemaknaan sebuah pelarian baru yaitu wanita. Dengan hadirnya Ellie, John merasakan kebebasan hidup yang tidak dialaminya selama ini. Tokoh Ellie ditambahkan untuk memaknai kebebasan John melalui cerita pertemuannya dengan seorang wanita pembawa kebebasan.

"The car begins to move and work its way onto the streets. Before he knows it, it's way past midnight and they're still driving with the top down. The wind makes her hair move like something he's never seen before. He doesn't know her well, except what little he's heard from Midnite, and she's far more mysterious than be's comfortable with. But there's something in her that makes him feel alive, like he wants to live for the good of life for once and he doesn't quite know what it is about her that makes him feel that way. Wherever they're going, he doesn't care just as long as he has the mysterious brunette by bis side. He thinks he'll give her the chance to prove different from the other whores. Maybe in this one, he'll find something worth his while" (TravelingThroughTime: 2008).

Cerita TravelingThroughTime tentang pertemuan John dengan Ellie, memberikan sebuah pemaknaan terhadap tokoh John mengenai keinginannya untuk membuat hidupnya lebih berharga, yang kemudian terakomodasi melalui tokoh Ellie. Di dalam film Constantine, digambarkan hidup John Constantine telah dikutuk, disebabkan karena pada waktu dia masih anak-anak, dia mencoba bunuh diri karena merasa tidak kuat dengan kemampuannya melihat hal-hal gaib. Oleh sebab itu, jiwanya telah dikutuk dan diinginkan oleh neraka, dan tidak lain, Lucifer sendiri yang berniat akan mencabut nyawanya dan membawanya ke neraka. Mengetahui hal ini, John mengabdikan diri menjadi pengusir setan sebagai investasi menuju surga. Namun dia sering mengalami depresi dengan kemampuan dan pekerjaannya berhadapan dengan setan dan malaikat. Kecanduan akan rokok membuatnya mengidap penyakit kanker, paruparunya bermasalah, namun, John bersikeras tidak ingin menghentikan kebiasaannya merokok, dia ingin melakukan apa yang dia suka selagi dia masih hidup, karena jiwanya sudah dikutuk akan masuk neraka. Rokok diperbincangkan sebagai produk ketika orang menemukaan ekstase di dalam tekanan-tekanan yang melingkupinya. Ketika ekstase dicapai, hal-hal pendukung pencapaian diperjuangkan, serta menyingkirkan pengaruh-pengaruh yang memperpanjang jarak dengan sumber kesenangan. Ekstase merupakan gambaran seseorang ketika menemukan kesenangan dengan mengorbankan hal berharga untuk 
mencoba keluar dari berbagai tekanan. John Constantine mengorbankan kesehatan dirinya demi mencapai kesenangannya menghisap rokok. Kemudian wanita, Ellie, dihadirkan oleh audiens film Constantine, TravelingThroughTime, untuk memaknai ekstase John Constantine. Ekstase didapatkan John ketika Ellie mengajaknya keluar mengendarai mobil tanpa tujuan jelas. Rokok kemudian digantikan oleh seorang wanita, John merasa dirinya hidup kembali dengannya, merasakan hidupnya lebih berharga dari sebelumnya, sebuah ekstase telah diraihnya melalui media lain, yaitu Ellie.

Pemaknaan akan sebuah ekstase John Constantine, mampu dilakukan oleh audiens film Constantine. Dengan masih menggunakan tokoh dalam film, audiens menciptakan cerita baru sehingga memunculkan makna baru pula. Usaha audiens atau fans ini merupakan bentuk komunikasi dialektis antara media dengan audiens. Mereka tidak menerima konten media secara pasif namun aktif menginterpretasi dan memaknai. Audiens aktif, memberikan pandangan bahwa, dengan munculnya media baru, intenet, dengan terakomodasinya keinginan untuk memaknai dan mempublikasikan pemaknaan secara luas, maka demokratisasi dalam praktik bermedia dapat tercipta.

Pemaknaan lain tentang film Constantine, juga diutarakan oleh audiens bernama akun Genius-626, melalui cerita fiksinya yang dipublikasikan di situs www.fanfiction.net, berjudul Ticket to Heaven. Dia mengelaborasi psikologis John Constantine, keinginan, harapan beserta tujuan hidupnya, ketakbermaknaan hidupnya di dunia, menimbulkan harapan akan sebuah makna yang akan dia temukan setelah hidupnya berakhir. Hidupnya telah dikutuk, trauma semasa kecil dan tersiksa oleh tekanan berhadapan dengan iblis. Tak dapat dipungkiri, dia memiliki keinginan mulia akan sebuah keabadian, namun dia terus menyangkalnya.

"He would have never admitted it - to anyone-but be wanted to go to Heaven. This want was no ordinary desire, this was a goal, the only goal a near soulless man had to live for. The afterlife was the only thing he had to look forward to, eternity substantially more important than this immortal "life." He knew this world too well, and he hated it. Nothing had ever appealed to him, having been scarred as a child; neglected as well as tormented by the demons. He had no place, though seemed to have a purpose, this purpose supposedly self-explanatory. He worked at the mercy of others-to help others-but for selfish reasons, therefore never gaining the acceptance he craved. Ob how he craved nothing else" (Genius-626: 2012).

Film Constantine juga turut menyimpan perbincangan tentang tujuan hidup. Secara filosofis, tujuan hidup dimaknai sebagai sebuah kebahagiaan, bebas tanpa tekanan, keadaan dimana hasrat dan keinginan sudah tidak ada lagi. John Constantine begitu mendambakan keadaan tersebut, kemampuannya dalam melihat dan berhadapan dengan makhluk-makhluk gaib dianggap sebagai sebuah kutukan bagi dirinya, bukan berkah. Ditambah dengan keinginan kuat Lucifer untuk mencabut nyawanya dan membawanya sendiri ke neraka, membuatnya semakin sulit untuk mencapai tujuannya, yang tak lain adalah, surga. Interpretasi akan tujuan hidup John Constantine, disampaikan melalui pengembangan cerita tentang bagaimana perjalanan JohnConstantine dalammeraih surga. Di film diceritakan, bahwa John mengabdikan dirinya sebagai pengusir setan sebagai investasi menuju surga. Juga, pengorbanannya, melakukan bunuh diri untuk memanggil Lucifer dan membawa anaknya, Mammon, kembali ke neraka, telah menghambat jiwanya untuk masuk neraka. Cerita ini kemudian dimaknai dengan mengelaborasi bentuk lain dari investasi John menuju surga. Pada awalnya, menjadi pengusir setan adalah investasinya, namun ada faktor lain yang lebih kuat, yang mengantarkannya untuk menuju surga.

Genius-626 memberikan pemaknaan investasi John menuju surga dengan membuat cerita fiksi, melanjutkan cerita dalam film dan memberikan detil-detil adegan yang tidak ditampilkan dalam film. Genius-626 menambahkan cerita setelah film berakhir, 
ketika Mammon berhasil dibawa kembali ke neraka, John hidup kembali begitu juga dengan Angela. Adegan ditambahkan dengan pertemuan kembali John dengan Angela, pertemuan yang tidak sempat ditentukan secara pasti bagaimanakah kelanjutan hubungan mereka berdua, dan juga ada rahasia yang belum terungkap tentang misteri kehidupan John Constantine setelah pergulatannya dengan Gabriel, Lucifer dan Mammon. Berikut cerita lanjutannya, adegan pertemuan John dengan Angela.

"This is my third chance at life, Angela. Without you, I wouldn't be here. Or..." his eyes flicked up for a second. "Accepted. You're my ticket to Heaven, you know that? So I'm sorry, but I'll have to bold onto you for a while. Probably until I die. Not that you have a choice or anything."

She couldn't help but smile at this, knowing the real truth. He'd done the right thing in self sacrifice to earn his way to Heaven, she wasn't the key or his "ticket" even if it was her he did it for.

"That's probably the sweetest thing I've ever heard you say. I shouldn't get used to that, should I?"

Now be was smiling, completely uncaring about sharing with her his happiness. "No, I wouldn't count on it." (Genius-626: 2012)

John Constantine telah merubah hidupnya, dia telah menghentikan kebiasaannya merokok dan menggantinya dengan mengunyah permen karet. John digambarkan telah semakin dekat dengan jalan surga. Pemaknaan bentuk investasi John yang baru menuju surga bukan lagi pada pekerjaannya sebagai pengusir setan, namun pada sebuah hal yang tidak dia sangka-sangka, tindakan yang tidak dia sadari akan mengantarkannya menuju surga, dia hanya melakukannya dengan tulus yaitu, pengorbanan cinta. Pendambaan John akan surga, terealisasikan melalui seorang wanita, yang tak lain adalah Angela. Oleh karena itu, John menyebut Angela sebagai tiket untuknya menuju surga, namun sebenarnya pengorbanan demi Angela itulah yang membukakan pintu dan jalan menuju surga. John serasa mendapatkan hidupnya kembali, dan menemukan cara bagaimana menuju surga, yang kemudian merubah hidupnya dengan menginvestasikan, serta mengabdikan dirinya hanya pada satu hal yaitu cinta. Lebih tepatnya cintanya kepada Angela.

Pemaknaan film oleh audien, Genius-626, merupakan praktik bagaimana seorang audien menggunakan media. Ia menggunakan media, khususnya situs www.fanfiction.net, untuk mempublikasikan karya fiksinya beserta interpretasinya tentang film Constantine. Dengan hadirnya ruang fanfiction, maknamakna baru akan terus muncul dari audiens tentang konten media baik berupa film, novel, buku dan program televisi. Makna menjadi kaya, plural dan heterogen, karena terjadinya komunikasi dialektis antara audiens dengan media. Audiens mampu memproduksi makna dari intepretasinya terhadap media, serta juga mampu mempublikasikannya secara luas, kemudian diinterpretasi oleh audiens lain dan memunculkan makna-makna baru lagi.

\section{Kesimpulan}

Media tradisional seperti televisi, memiliki sistem komunikasi transmisif, yaitu berjalan satu arah, ada pengirim dan penerima. Pengirim berasal dari agen media dengan audiens sebagai penerima. Audiens tidak diberi kesempatan untuk memproduksi makna dari konten media yang disampaikan, maka dari itu sifat audiens menjadi pasif. Namun, ketika internet hadir, inilah saat untuk merayakan pluralitas makna. Makna tidak hanya diproduksi oleh agen media, namun audiens, melalui media internet, mampu memproduksi makna tentang konten media serta mempublikasikannya secara global. Audiens bukan lagi sebagai objek pasif melainkan berubah menjadi subjek aktif. Seperti dalam ranah fancition atau disebut juga fiksi penggemar, audiens atau fans mempunyai kebebasan untuk memproduksi cerita fiksi tentang resepsi karya-karya berupa film, novel, buku, komik dan program televisi.

Seperti dalam film Constantine, audiens film mampu memproduksi cerita fiksi dengan masih 
menggunakan karakter-karakter dan setting film tersebut. Salah satu audien bernama akun TravelingThroughTime, dalam www.fanfiction. net, mencoba memberikan pemaknaan baru tentang ekstase John Constantine. Semula rokok menjadi produk, media pencapaian kenikmatan, sampai dia mengorbankan kesehatannya demi memperjuangkan kebiasaannya merokok. TravelingThroughTime memproduksi makna ekstase baru untuk Constantine yaitu seorang wanita. Wanita menggantikan rokok sebagai sosok yang mengantarkannya pada sebuah kebebasan, keberhargaan hidup dan pelarian baru. Pemaknaan lain tentang film Constantine, turut dilakukan oleh audien bernama akun Genius-626, dengan menambahkan plot ceita beserta dengan detil-detil adegannya. Dengan masih menggunakan tokoh utama, pemaknaan akan investasi menuju surga, dilakukan dengan memberikan cerita lanjutan setelah adegan ending film. Dalam film, John Constantine mengabdikan dirinya menjadi seorang pengusir setan sebagai investasinya menuju surga, namun kemudian Genius-626 memaknai ulang investasi sebenarnya yang mengantarkan John menuju surga, yang secara tidak sadar tindakannya telah membuka jalan menuju surga, dia hanya melakukannya dengan tulus yaitu dengan mengorbankan dirinya demi Angela. Angela adalah tiketnya menuju surga, lebih tepatnya pengorbanan cinta kepadanya.

Media fanfiction memberikan kesempatan bagi audiens untuk memproduksi makna dari resepsi konten media, sekaligus juga mempublikasikannya secara luas. Audiens mampu menciptakan karya fiksi tentang sebuah film, novel, buku ataupun program televisi dengan masih menggunakan karakter-karakter dan setting dalam media tersebut. Dengan begitu, sitem komunikasi dialektis antara audiens dengan media ini, akan memunculkan berbagai macam makna-makna baru dari beragam interpretasi yang berbeda-beda. Pluralitas makna, sistem komunikasi dialektis, dan akses mudah dalam bermedia mengantarkan untuk lebih dekat kepada demokrasi media.

\section{Daftar Pustaka}

Hall, Stuart. "Encoding, Decoding" dalam Simon During (Eds.) (1993). The Cultural Studies Reader (Second Edition). London:Routledge

Hesmondhalgh, David. 2010. "User-Generated Content, free labour and the cultural industries", Ephemera: Theory and Politics in Organization, 10(3-4):267-284

Severin W. J., \& Tankard, J. W. "Uses of Mass Media” dalam Severin, W. J. \& J. W. Tankard (Eds.) (1997). Communication Theories: Origins, Methods, and Uses in the Mass Media (4th ed.). New York:Longman

TravelingThroughTime, 2008, "Smoke, Drink And Learn To Love," dalam fanfiction.net, URL:http://www. fanfiction.net/s/4692403/1/SmokeDrink-And-Learn-To-Love (akses 22 Juni 2013)

Genius-626. 2012. "Ticket to Heaven," dalam fanfiction.net. URL: http://www. fanfiction.net/s/7797087/1/Ticket-toHeaven (akses 22 Juni 2013) 